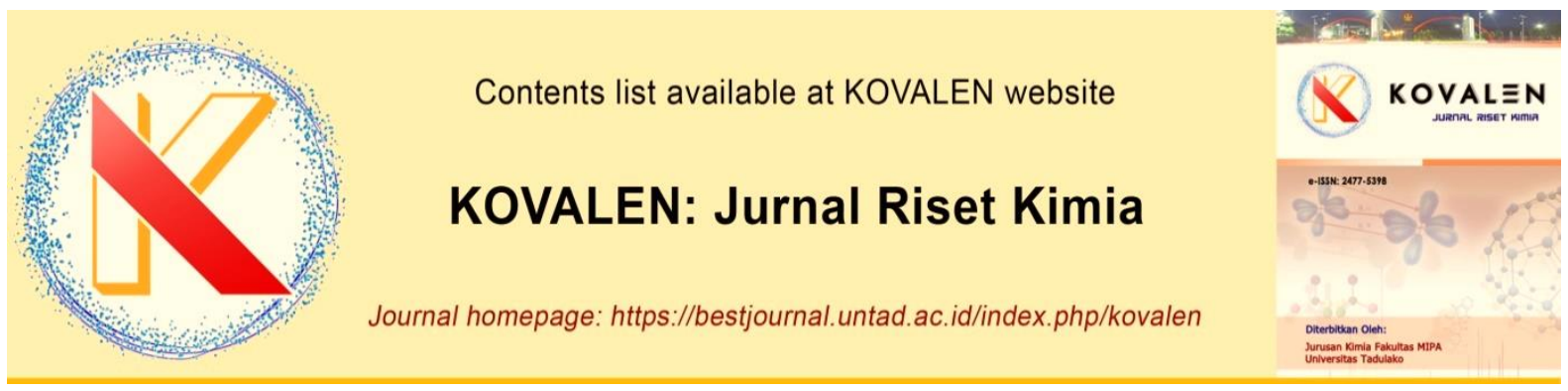

\title{
Pengaruh Kadar Air dan Kadar Asam Lemak Bebas Terhadap Masa Simpan Minyak Kelapa Mandar
}

\section{[The Influence of Water Content and Free Fatty Acid Content on Mandar Coconut Oil Shelf Life]}

\author{
Musafira $^{1 *}$, Dzulkifli $^{2}$, Fardinah $^{1}$, Nizar $^{3}$ \\ ${ }^{1}$ Fakultas MIPA, Universitas Sulawesi Barat, Indonesia \\ ${ }^{2}$ Fakultas Teknik, Universitas Sulawesi Barat, Indonesia \\ ${ }^{3}$ Fakultas Pertanian dan Kehutanan, Universitas Sulawesi Barat, Indonesia \\ *Corresponding author: musafira@unsulbar.ac.id
}

\begin{abstract}
Mandar coconut oil made in Tulu village, Majene regency, West of Sulawesi, is very popular among Sulawesi Barat people. It is because the unique aroma which is not owned by other Mandar oil traders. In addition, according to Mandar coconut oil trader who is also the produsen of Mandar oil said that his coconut oil could be stored for months. This research aimed to know the influence of water content and free fatty acid content on Mandar coconut oil shelf life. Gravimetric Method and Alkaline method were used to determine the water content and the free fatty acid content respectively. The oil was stored at room temperature. Water content and free acid content were measured every week, i.e week zero to week four ( 5 observations). Shelf life estimation was done by applying the kinetic theory. The result shows that the water content and the free fatty acid content increase as shelf life increases. Mandar coconut oil can be stored at room temperature for 1 month, 12 days.
\end{abstract}

Keywords: Mandar coconut oil, water content, free fatty acid, shelf life

ABSTRAK. Minyak kelapa Mandar yang dibuat di kampung Tulu, Kabupaten Majene Propinsi Sulawesi Barat, sangat disukai oleh masyarakat Mandar. Hal ini dikarenakan aromanya yang khas dan tidak banyak dimiliki oleh pembuat minyak Mandar di tempat lain. Disamping itu, menurut salah seorang pedagang yang juga produsen minyak kelapa mandar mengatakan bahwa minyak kelapanya dapat bertahan berbulan-bulan Penelitian ini bertujuan untuk mengetahui pengaruh kadar air dan kadar asam lemak bebas terhadap masa simpan minyak kelapa Mandar. Metode analisis yang digunakan untuk menganalisis kadar air dan kadar asam lemak bebas adalah metode gravimetric dan metode alkalimetri. Minyak disimpan pada suhu ruang dan dianalisis kadar air dan kadar asam lemak bebas setiap minggu, dimulai dari minggu ke 0 hingga minggu ke 4 (5 pengamatan). Untuk pendugaan masa simpan minyak dilakukan dengan menerapkan teori kinetika. Hasil yang diperoleh menunjukkan bahwa kadar air dan kadar asam lemak bebas meningkat seiring bertambahnya waktu penyimpanan. Miyak kelapa Mandar dapat disimpan pada suhu selama 1 bulan 12 hari.

Kata kunci : Minyak kelapa Mandar, kadar air, kadar asam lemak bebas, masa simpan

Riwayat artikel: Diterima 18 November 2020, Disetujui 5 Desember 2020

Cara sitasi: Musafira., Dzulkifli., Fardinah., \& Nizar. (2020). Pengaruh Kadar Air dan Kadar Asam Lemak Bebas Terhadap Masa Simpan Minyak Kelapa Mandar. KOVALEN: Jurnal Riset Kimia, 6(3): 224-229.

DOI: https://doi.org/10.22487/kovalen.2020.v6.i3.15344 


\section{LATAR BELAKANG}

Majene merupakan salah satu daerah penghasil kelapa di Indonesia, dengan jumlah produksi kelapa mencapai 9687,64 ton (BPTP Sulbar, 2016). Kelapa dikenal sebagai tanaman yang multifungsi karena hampir semua bagian dari tanaman kelapa mulai dari batang, daun hingga buahnya dapat digunakan untuk berbagai keperluan. Di antara bagian tanaman kelapa, daging buah kelapa yang paling banyak dimanfaatkan oleh masyarakat baik sebagai makanan maupun diolah menjadi minyak.

Pembuatan minyak dari kelapa telah banyak dilakukan oleh masyarakat desa tak terkecuali masyarakat di Kampung Tulu, Labuang Kecamatan Banggae Timur Kabupaten Majene. Desa ini dikenal sebagai Kappung Pappolana yakni daerah penghasil minyak kelapa Mandar. Proses pembuatan minyak kelapa di desa ini menggunakan cara tradisional, yakni minyak dibuat dari santan kental dengan teknik pemanasan atau dikenal dengan cara basah (Nasruddin, 2011). Minyak yang dihasilkan didaerah ini memiliki aroma wangi yang tidak banyak dimiliki oleh pembuat minyak Mandar di tempat lain (Djamaan, 2017). Disamping itu, menurut salah seorang pedagang yang juga produsen minyak kelapa mandar mengatakan bahwa minyak kelapanya dapat bertahan berbulan-bulan. Kekhasan aroma minyak kelapa Mandar dan pemahaman masyarakat mandar bahwa minyak kelapa mandar dapat disimpan berbulan-bulan menyebabkan masyarakat mengkonsumsi minyak kelapa Mandar.

Menurut Nasruddin (2011) dan Asni \& Yanti (2014), pembuatan minyak kelapa dengan cara tradisional memiliki kualitas rendah sehingga berbahaya bagi kesehatan apabila dikonsumsi. Hal ini dikarenakan minyak goreng dari kelapa yang diolah secara tradisional tidak memenuhi syarat standar mutu minyak goreng kelapa yang tertuang dalam Standar Nasional Indonesia (SNI) 0129021992 (Tabel 1). Diantara parameter yang tertuang dalam SNI tersebut, parameter kimia yang sangat memperngaruhi kualitas minyak. Menurut (Prabowo et al., 2016), penyimpanan minyak dapat menyebabkan terjadinya kerusakan minyak akibat adanya proses hidrolisis dan oksidasi. Kerusakan minyak dapat diketahui dari peningkatan kadar air dan kadar asam lemak bebas.

Tabel 1. Standar mutu minyak kelapa berdasarkan SNI 01-2902-1992 (Badan Standardisasi Nasional, 2011)

\begin{tabular}{clc}
\hline No. & \multicolumn{1}{c}{ Karakteristik } & Syarat Mutu \\
\hline 1. & Bau & Tidak berbau \\
2. & Rasa & Normal \\
3. & Warna & Putih kuning \\
4. & Kadar air (\%) & Maks. 0.5 \\
5. & Kadar kotoran (\%) & Maks. 0.05 \\
6. & Bilangan Jod (mg & $8-10$ \\
& $\begin{array}{l}\text { jod/100 g contoh) } \\
\text { 7. }\end{array}$ & Bilangan peroksida \\
& (mg oksigen/g contoh) & Maks. 5 \\
8. & $\begin{array}{l}\text { Bilangan penyabunan } \\
\text { (mg KOH/g contoh) }\end{array}$ \\
9. & Asam lemak bebas & 255 -265 \\
\hline
\end{tabular}

Berdasarkan hal tersebut di atas, maka perlu dilakukan penelitian tentang analisis kualitas minyak goreng dari kelapa (minyak kelapa Mandar) dan pendugaan masa simpan minyak tersebut pada suhu ruang. Diharapkan melalui penelitian ini masyarakat dapat mengetahui kualitas minyak goreng yang mereka konsumsi dan dapat mengetahui seberapa lama mereka dapat menyimpan minyak tersebut. 


\section{METODE PENELITIAN}

\section{Bahan dan Alat}

Bahan yang digunakan dalam penelitian ini adalah minyak goreng dari kelapa (minyak Mandar) yang diperoleh dari salah satu pedagang minyak goreng di Kampung Tulu, Labuang Kecamatan Banggae Timur Kabupaten Majene Bahan lain sebagai pendukung dan bahan kimia untuk analisis diantaranya: $\mathrm{NaOH} 0,1 \mathrm{~N}$, alkohol 95\% panas, akuades, indikator pp.

Peralatan penelitian meliputi: oven, desicator, neraca analitik, cawan porselen, buret, klem dan statif dan beberapa alat gelas yang umum digunakan dalam laboratorium

\section{Prosedur Penelitian}

\section{Pendugaan masa simpan minyak kelapa mandar}

Minyak kelapa yang diperoleh dari salah seorang pedagang di kampung Tulu, kabupaten Majene Sulawesi Barat, dimasukkan ke dalam botol dan di simpan dalam suhu ruang. Penyimpanan dilakukan selama 4 minggu dengan pengamatan sebanyak 5 kali.

Analisis yang dilakukan untuk mengetahui kualitas minyak mandar adalah kadar air (Fanani \& Ningsih, 2018) dan kadar asam lemak bebas (AOAC, 1999). Dari hasil analisis ditentukan nilai deterninasi tertinggi dari kedua parameter tersebut, untuk dijadikan parameter kritis. Parameter kritis tersebut digunakan untuk mengetahui masa simpan minyak dengan menggunakan pendekatan secara kinetika.

\section{Perhitungan pendugaan masa simpan (Susanti \& Siregar, 2016)}

Pendugaan masa simpan minyak dilakukan dengan menerapkan teori kinetika reaksi. Berdasarkan teori kinetika, penurunan kualitas produk pangan dapat digolongkan berdasarkan orde reaksi sebagai berikut :

a. Reaksi orde nol

$$
-d[A] / d t=k
$$

Dengan mengintegralkan persamaan di atas, maka akan diperoleh persamaan :

$$
[A] \mathrm{t}=[\mathrm{A}]_{0}-\mathrm{Kt}
$$

Keterangan :

$$
\begin{aligned}
\mathrm{A}= & \text { Kadar parameter yang diamati } \\
\mathrm{k}= & \text { konstanta kecepatan bertambahnya } \\
& \text { atau menurunnya parameter yang } \\
& \text { diamati } \\
\mathrm{t}= & \text { waktu }
\end{aligned}
$$

b. Reaksi orde satu

$$
-d[A] / d t=k[A]
$$

Dengan menyusun dan mengintegralkan persamaan di atas, maka akan diperoleh persamaan :

$$
\begin{aligned}
& -\int_{A_{0}}^{A} \frac{d[A]}{A}=k \int_{0}^{t} d t \\
& -\ln \frac{[A]}{\left[A_{0}\right]}=k . t \\
& \ln [A]=-k . t+\ln \left[A_{0}\right] \\
& \ln [\mathrm{A}] \mathrm{t}=\ln [\mathrm{A}]_{0}-\mathrm{kt} \quad \ldots \ldots . .
\end{aligned}
$$

\section{HASIL DAN PEMBAHASAN}

\section{Kualitas Minyak Mandar Selama Penyimpanan}

\section{Kadar FFA minyak}

Pada Tabel 2 dan Gambar 1, dapat dilihat bahwa kadar FFA semakin meningkat seiring dengan bertambahnya waktu penyimpanan. Hal ini membuktikan telah terjadi reaksi hidrolisis. Minyak kelapa mengandung lebih banyak asam lemak jenuh sehingga lebih mudah mengalami hidrolisis (Nasruddin, 2011; Prabowo et al., 2016). Hidrolisis terjadi karena terdapat sejumlah air dalam minyak tersebut 
dan menyebabkan terbentuk asam lemak bebas dan gliserol. Kadar asam lemak bebas yang tinggi dapat berpengaruh pada peningkatan kadar kolesterol dalam darah, sehingga dapat menyebabkan masalah kesehatan (Fanani \& Ningsih, 2018).
Disamping itu, minyak yang mengandung asam lemak bebas yang tinggi dapat menyebabkan ketengikan pada minyak bila disimpan dalam waktu tertentu tanpa pengawetan (Nasruddin, 2011).

Tabel 2. Kadar FFA minyak kelapa mandar selama penyimpanan

\begin{tabular}{ccccccc}
\hline \multirow{2}{*}{$\begin{array}{c}\text { Parameter yang } \\
\text { diuji }\end{array}$} & \multicolumn{3}{c}{ Waktu Penyimpanan (minggu) } & & $\begin{array}{c}\text { Syarat mutu } \\
\text { SNI. }\end{array}$ \\
\cline { 2 - 5 } & Minggu 0 & Minggu 1 & Minggu 2 & Minggu 3 & Minggu 4 & 01-2902-1992 \\
\hline $\begin{array}{c}\text { Kadar Asam } \\
\text { lemak bebas (\%) }\end{array}$ & 0.80 & 1.08 & 1.50 & 1.98 & 2.65 & Maks. 5 \\
\hline
\end{tabular}

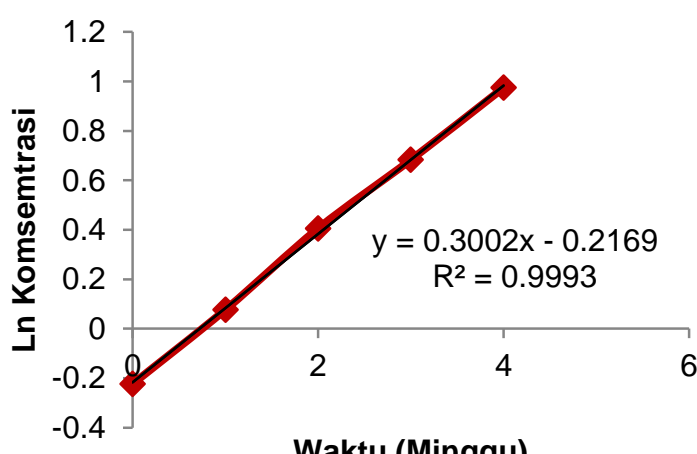

Waktu (Minggu)

Gambar 1. Hubungan antara Ln kadar FFA dengan waktu penyimpanan

\section{Kadar air minyak}

Hasil pengukuran kadar air dari minyak kelapa selama penyimpanan pada suhu ruang dapat dilihat pada Tabel 3. Berdasarkan Tabel 3, diketahui bahwa kadar air selama penyimpanan pada suhu ruang cenderung meningkat Pada saat minggu ke nol kadar air masih memenuhi standar SNI. Kadar air dari minyak kelapa mandar yang diperoleh dari penelitian ini lebih rendah dibanding dengan kadar air dari minyak kelapa yang diproduksi secara tradisional di provinsi Jambi (Asni \& Yanti, 2014). Hal ini disebabkan karena pada proses pembuatan minyak kelapa mandar, kelapa yang digunakan seragam yakni kelapa tua yang diparut dan langsung diambil santannya. Pada saat minggu ke 1 kadar air sudah mulai meningkat dan terus meningkat hingga minggu ke empat. Hal ini mungkin disebabkan karena terjadinya reaksi oksidasi asam lemak tidak jenuh dalam minyak yang menghasilkan gas $\mathrm{CO}_{2}$, asam volatile, aldehid dan sejumlah molekul air. Kandungan asam lemak tidak jenuh pada minyak kelapa sekitar 5.0-11.5\% (Sirait et al., 1996).

Tabel 3. Kadar air minyak kelapa mandar selama penyimpanan

\begin{tabular}{ccccccc}
\hline \multirow{2}{*}{$\begin{array}{c}\text { Parameter yang } \\
\text { diuji }\end{array}$} & \multicolumn{3}{c}{ Waktu Penyimpanan (minggu) } & & $\begin{array}{c}\text { Syarat mutu } \\
\text { SNI. }\end{array}$ \\
\cline { 2 - 5 } & Minggu 0 & Minggu 1 & Minggu 2 & Minggu 3 & Minggu 4 & 01-2902-1992 \\
\hline Kadar Air (\%) & 0.03 & 0.14 & 0.27 & 0.37 & 0.84 & Maks. 0.5 \\
\hline
\end{tabular}




\section{Masa simpan minyak}

Penentuan waktu simpan dari minyak kelapa mandar dilakukan untuk mengetahui waktu yang diperlukan oleh minyak dalam suatu kondisi penyimpanan untuk sampai pada suatu leval mutu minyak yang masih memenuhi syarat dikonsumsi (Vitasari et al., 2016). Penentuan waktu simpan dilakukan dengan menggunakan teori kinetika. Umumnya penurunan kualitas bahan pangan mengikuti persamaan kinetika orde 1 (Islamiyah et al., 2013). Akan tetapi, untuk mencari nilai koefisien determinasi yang lebih tinggi $\left(R^{2}\right)$ maka penentuan kualitas minyak dengan persamaan kinetika orde 0 juga dilakukan.

Tabel 4. Nilai $\mathrm{R}^{2}$ dari persamaan orde o dan orde 1 untuk setiap parameter

\begin{tabular}{cccc}
\hline No. & $\begin{array}{c}\text { Paremter yang } \\
\text { dianalisa }\end{array}$ & Nilai $\mathrm{R}^{2}$ untuk orde 0 & Nilai $\mathrm{R}^{2}$ untuk orde 1 \\
\hline 1 & Kadar air & $\mathrm{y}=0.185 \mathrm{x}-0.04$ & $\mathrm{y}=0.763 \mathrm{x}-3.117$ \\
& & $\mathrm{R}^{2}=0.874$ & $\mathrm{R}^{2}=0.932$ \\
2 & Kadar FFA & $\mathrm{y}=0.46 \mathrm{x}+0.682$ & $\mathrm{y}=0.300 \mathrm{x}-0.216$ \\
& & $\mathrm{R}^{2}=0.976$ & $\mathrm{R}^{2}=0.999$ \\
\hline
\end{tabular}

Berdasarkan Tabel 4, baik kadar air maupun kadar FFA memiliki nilai $\left(\mathrm{R}^{2}\right)$ mendekati 1 sehingga laju konsumsi air dan laju produksi asam lemak bebas mengikuti kinetika orde 1. Pada Gambar 1, diperoleh nilai $k$ yakni 0,300 . Dengan menggunakan nilai $k$ maka masa simpan minyak pada suhu ruang untuk kadar FFA maksimum 5\% (SNI) adalah:

$$
\begin{aligned}
& t=\frac{2,303 \cdot \log A t / A o}{k} \\
& t=\frac{2,303 \cdot \log 5 / 0,8}{0,300} \\
& t=6 \text { minggu }
\end{aligned}
$$

Dengan demikian masa simpan minyak Mandar pada suhu ruang adalah 1 bulan 12 hari.

\section{KESIMPULAN}

Berdasarkan hasil penelitian ini, dapat disimpulkan bahwa semakin lama disimpan mutu minyak kelapa Mandar semakin rendah, yang ditandai dengan kadar FFA dan kadar air minyak kelapa Mandar yang melebihi SNI. Masa simpan minyak Mandar pada suhu ruang adalah 1 bulan 12 hari.

\section{DAFTAR PUSTAKA}

AOAC. (1999). Official Methods of Analysis of the Association of Official Analytical ChemistInternational. 16thed. AOAC Inc.

Asni, N., \& Yanti, L. (2014). Identifikasi Dan Analisis Mutu Minyak Kelapa Di Tingkat Petani Provinsi Jambi. Balai Pengkajian Teknologi Pertanian Jambi. Prosiding Konferensi Nasional Kelapa VIII. Konferensi Nasional Kelapa VIII, 21-22 Mei 2014, Balitbangtan Kementan, Jambi.

Badan Standardisasi Nasional. (2011). Minyak kelapa mentah SNI 2902: 2011. Badan Standardisasi Nasional, Jakarta.

BPTP Sulbar. (2016). Membangun model bio industry kelapa di Kab. Majene. Balitbangtan Sulawesi Barat. http://sulbar.litbang.pertanian.go.id/ind l.

Djamaan, A. (2017). Kampung Tulu Banggae, Potensi wisata budaya pembuatan minyak kelapa tradisional mandar. (http://kompadansamandar.blogspot.c om/2017/07/kampung-tulu-banggaepotensi-wisata-budaya-pembuatanminyak-kelapa-tradisional- 
mandar.html. diakses pada tanggal 22 November 2019).

Fanani, N., \& Ningsih, E. (2018). Analisis Kualitas Minyak Goreng Habis Pakai yang Digunakan oleh Pedagang Penyetan di Daerah Rungkut Surabaya Ditinjau dari Kadar Air dan Kadar Asam Lemak Bebas (ALB). Jurnal IPTEK, 22(2): 59-66. https://doi.org/10.31284/j.iptek.2018.v 22i2.436

Islamiyah, U., Gonggo, S., \& Pursitasari, I. (2013). Profil Kinetika Perubahan Kadar Glukosa Pada Nasi Dalam Pemanas. Jurnal Akademika Kimia, 2(3): 160-165.

Nasruddin. (2011). Studi kualitas minyak goreng dari kelapa (Cocos nucifera L.) melalui proses sterilisasi dan pengepresan. Jurnal Dinamika Penelitian Industri, 22(1): 9-18. https://doi.org/10.28959/jdpi.v22i1.534

Prabowo, P., Sulaeman, R., \& Budiani, E. S. (2016). Uji Masa Simpan Kualitas Minyak Hasil Ekstraksi Biji Buah Bintaro (Cerbera manghas L) Sebagai Bahan Baku Biodiesel. Jurnal Online Mahasiswa (JOM) Bidang Pertanian, 3(2): 1-9.

Sirait, S., Widiyanti, S., \& Bunasor, T. (1996). Pengaruh Metode Ekstraksi Dan Lama Penyimpanan Terhadap Mutu Minyak Kelapa Kasar. Warta IHP, 13(1-2).

Susanti, I., \& Siregar, N. C. (2016). Karakterisasi dan Pendugaan Daya Tahan Simpan Bio Oil (Minyak Alpukat dan Minyak Buah Merah). Warta Industri Hasil Pertanian, 33(02): 57-65. https://doi.org/10.32765/warta inp.v33i02.3818

Vitasari, L., Mappiratu, M., \& Sumarni, N. K. (2016). Retensi Asam Eikosapentaenoat (EPA) Tortilla Tepung Ikan Lele Selama Pengolahan Dan Penyimpanan Pada Suhu Ruang. KOVALEN: Jurnal Riset Kimia, 2(2). http://jurnal.untad.ac.id/jurnal/index.ph $\mathrm{p} /$ kovalen/article/view/6721 